\title{
Altered expression of IGFs and IGF-binding proteins during intrauterine growth restriction in guinea pigs
}

\author{
A M Carter ${ }^{1,2}$, M J Kingston ${ }^{1}$, K K Han ${ }^{1}$, D M Mazzuca ${ }^{1}$, \\ K Nygard ${ }^{1}$ and V K M Han ${ }^{1,3}$ \\ ${ }^{1}$ Child Health Research Institute, University of Western Ontario, London, Ontario N6C 2V5, Canada \\ ${ }^{2}$ Department of Physiology and Pharmacology, University of Southern Denmark, Winsløwparken 21, DK-5000 Odense, Denmark \\ ${ }^{3}$ Departments of Paediatrics, Obstetrics and Gynaecology, Biochemistry, Anatomy and Cell Biology, CIHR Group in Fetal and Neonatal Health and \\ Development, Child Health Research Institute, London, Ontario N6A 4GS, Canada \\ (Requests for offprints should be addressed to V K M Han; Email: vhan@uwo.ca)
}

\begin{abstract}
The IGF system is one of the most important endocrine and paracrine growth factor systems that regulate fetal and placental growth. We hypothesized that intrauterine growth restriction (IUGR) in guinea pigs is mediated by the altered expression of IGFs and/or IGF binding protein (BP) mRNAs in tissues and is related to growth of specific tissues. IUGR was induced by unilateral uterine artery ligation on day 30 of gestation, and fetal plasma, amniotic fluid and tissue samples were collected at 55-57 days (term about 68 days) from paired IUGR and control fetuses $(n=6)$. Western ligand blotting and immunoblotting were used to compare IGFBP levels in plasma and amniotic fluid. Total RNA was extracted from placenta and fetal tissues, and the relative abundance of IGF-II and IGFBP1-6 mRNA was determined by Northern blotting, using species-specific probes where available. IUGR fetuses had decreased $(P<0 \cdot 01$, by Student's $t$-test $)$ placental weight
\end{abstract}

and body weight with an increase in the brain:liver weight ratio. The principal IGFBPs in fetal plasma migrated at 40-35, 30 and $25 \mathrm{kDa}$ and were identified as IGFBP-3, -2 and -4 respectively. IUGR was associated with elevated plasma IGFBP-2 and IGFBP-4 and reduced IGFBP-3 levels. IGFBPs were detected at low levels in amniotic fluid of control fetuses but at higher levels in IUGR fetuses. In IUGR placentae, there was a small increase in IGFBP-4 mRNA $(P<0 \cdot 05)$. IGFBP-2 mRNA increased $(P<0 \cdot 001)$ in liver of IUGR fetuses. IGF-II and IGFBP mRNA expression did not change in fetal muscle. The results are consistent with reduced IGF action, directly or through inhibition by IGFBPs, particularly by circulating and tissue IGFBP-2, as a potential causal factor in decreased growth of the placenta and certain fetal tissues. Journal of Endocrinology (2005) 184, 179-189

\section{Introduction}

Insulin-like growth factors I and II (IGF-I and -II) are polypeptides with structural homology to proinsulin and are important in regulating fetal and placental growth (DeChiara et al. 1990, Liu et al. 1993). They promote proliferation, differentiation, migration and aggregation, and inhibit apoptosis; all processes involved in development. The bioavailability and biologic actions of IGFs are regulated by a family of six high-affinity binding proteins (BP) (IGFBP-1-6) (Clemmons 1997). In general, IGFBPs inhibit the actions of IGFs, by competing with the IGF receptors for the peptide. Slowing of fetal growth, as in intrauterine growth restriction (IUGR), probably involves decreased expression of IGFs and increased expression of IGFBPs.

Guinea pigs provide a valuable model for studying the developmental regulation of the IGF system. As in humans, IGF-II persists in the serum of adult guinea pigs, and IGF-II mRNA is expressed in adult tissues (Levinovitz et al. 1992). A further important similarity between guinea pig and human is the presence of IGFBP-3 in fetal plasma. This is in contrast to rats and mice, which lack postnatal expression of IGF-II (Soares et al. 1986, Rotwein \& Hall 1990) and prenatal expression of IGFBP-3 (D'Ercole \& Underwood 1980, Lee et al. 1999). There is $100 \%$ homology in the amino acid sequences of human and guinea pig IGF-I and -II and 96\% and 94\% homology in the nucleotide sequences of the respective mRNAs (Bell et al. 1990, Levinovitz et al. 1992). The cellular localization of IGF and IGFBP $\mathrm{mRNAs}$ in the placenta has been described in greater detail for the guinea pig than for any other nonprimate species (Han et al. 1999, Han \& Carter 2000).

Fetal growth restriction can be induced in guinea pigs by uterine artery ligation (Lafeber et al. 1984). Fetal body 
weight is reduced by about $40 \%$, but with brain sparing and an increase in brain:liver weight ratio. This model has been well characterized in terms of fetal endocrine and cardiovascular responses (Carter 1993). A previous report showed that circulating IGF-I levels are decreased and IGF-II levels are increased (Jones et al. 1987). Since IGF-II is a more important IGF during fetal development, the role of circulating IGFs in mediating the growth phenotype in this model is unclear. We therefore hypothesized that, in guinea pigs, IUGR is mediated by the altered expression of IGFBP mRNAs in tissues, and that this would be reflected in the protein levels in fetal plasma and related to changes in growth of specific tissues.

\section{Materials and Methods}

\section{Uterine artery ligation}

Unilateral uterine artery ligation was performed on day 30 of gestation in guinea pigs that had been given atropine $(0.05 \mathrm{mg}$ s.c. $)$ and anesthetized with ketamine $(4 \mathrm{mg} / \mathrm{kg}$ i.m.) and xylazine $(50 \mathrm{mg} / \mathrm{kg}$ i.m.), as previously described (Detmer \& Carter 1992).

\section{Tissue collection}

At 55-57 days of gestation, the dam was again anesthetized with ketamine and xylazine, and hysterotomy was performed. A fetus was taken from each horn of the uterus (ligated and control) in six guinea pigs. Unilateral pregnancies $(n=4)$ and experiments in which ligation resulted in fetal demise $(n=1)$ or failed to cause growth restriction $(n=1)$ were not included. As in our previous studies (Detmer \& Carter 1992, Carter 1993), we arbitrarily defined a growth-restricted fetus as one with a brain:liver weight ratio of $>0 \cdot 9$.

We took samples of amniotic fluid and collected fetal and maternal blood by cardiac puncture. Samples were collected on ice and the plasma and amniotic fluid stored at $-20{ }^{\circ} \mathrm{C}$. The dam was then killed by an overdose of pentobarbital sodium. The placenta (less the subplacenta), fetus and fetal organs were weighed. The placenta and fetal liver and muscle were divided into two parts. One part was snap frozen and stored at $-80{ }^{\circ} \mathrm{C}$ for total RNA; one part was immersion fixed in $4 \%$ paraformaldehyde in $70 \mathrm{mM}$ phosphate buffer at $4{ }^{\circ} \mathrm{C}$ for $48 \mathrm{~h}$ for in situ hybridization.

\section{Western ligand blot analysis}

The profile and relative levels of IGFBPs in fetal guinea pig plasma and amniotic fluid were determined by Western ligand blot analysis, as previously described (Delhanty \& Han 1993, Winger et al. 1997). Samples of plasma
$(10-20 \mu \mathrm{l})$ or amniotic fluid $(100 \mu \mathrm{l})$ were added to $20 \mu \mathrm{l}$ $6 \times$ Laemmli buffer $(160 \mathrm{mM}$ Tris-HCl $(\mathrm{pH} 6 \cdot 8), 4 \%$ SDS, $20 \%$ glycerol and $0.02 \%$ bromophenol blue), and sterile water was added to a total volume of $120 \mu \mathrm{l}$. The samples were boiled for $5 \mathrm{~min}$, quenched on ice for $2 \mathrm{~min}$ and then loaded onto a 6-12\% gradient non-reducing SDS-polyacrylamide gel and electrophoresed at constant voltage $(50 \mathrm{~V})$ overnight. The proteins were then transferred to a $0.2 \mu \mathrm{m}$ nitrocellulose membrane (Schleicher and Schuell, Keene, NH, USA) by electroblotting in Tris-glycine buffer $(25 \mathrm{mM}$ Tris, $1.192 \mathrm{mM}$ glycine and $20 \%(\mathrm{v} / \mathrm{v})$ methanol) at $4{ }^{\circ} \mathrm{C}$ at constant voltage $(50 \mathrm{~V})$ overnight. After transfer, the blots were washed in Tris$\mathrm{NaCl}$ buffer $(150 \mathrm{mM} \mathrm{NaCl}$ and $10 \mathrm{mM}$ Tris- $\mathrm{HCl}(\mathrm{pH}$ $7 \cdot 4)$ ) and blocked with Tris- $\mathrm{NaCl}$ buffer containing $1 \%$ $(\mathrm{w} / \mathrm{v})$ fatty acid-free bovine serum albumin (BSA) and $0 \cdot 1 \%$ Tween-20. The blots were hybridized with ${ }^{125} \mathrm{I}-$ labeled IGF-II for $20 \mathrm{~h}$ at $4{ }^{\circ} \mathrm{C}$ in $10-15 \mathrm{ml}$ Tris- $\mathrm{NaCl}$ buffer, $1 \%(\mathrm{w} / \mathrm{v})$ BSA and $0 \cdot 1 \%$ Tween-20. The blots were then washed in Tris- $\mathrm{NaCl}$ buffer $(\mathrm{pH} 7 \cdot 4)$, with and without $0 \cdot 1 \%$ Tween-20, air dried and exposed to radiographic film (BMR; Eastman Kodak, Rochester, NY, USA) at $-70{ }^{\circ} \mathrm{C}$ for $3-7$ days. They were analyzed by densitometry (PhosphorImager SI; Molecular Dynamics, Sunnyvale, CA, USA).

To identify IGFBPs present in plasma, parallel Western blots were prepared for ligand blotting and immunoblotting. Membranes for immunoblotting were blocked overnight at $4{ }^{\circ} \mathrm{C}$ in TTBS buffer $(150 \mathrm{mM} \mathrm{NaCl}, 50 \mathrm{mM}$ Tris-HCL ( $\mathrm{pH} 7 \cdot 4$ ) containing $0.05 \%$ Tween-20) and $4 \%(\mathrm{w} / \mathrm{v})$ fatty acid-free BSA. The blot was then washed three times with TTBS and incubated for $20 \mathrm{~h}$ in TTBS with $1 \%(\mathrm{w} / \mathrm{v})$ BSA and rabbit antiserum against bovine IGFBP-2 (no. 06-317; Upstate Biotechnology, Lake Placid, NY, USA) (1:2000), which cross-reacted with the guinea pig protein. After incubation with primary antiserum, the membranes were washed three times with TTBS and then incubated for $2 \mathrm{~h}$ with antirabbit immunoglobulin (Ig) G biotin conjugates (Sigma, Oakville, Ontario, Canada) (1:1000) diluted in TTBS with 1\% $(\mathrm{w} / \mathrm{v})$ BSA. Membranes were washed three times in TTBS, in ExtraAvidin (Sigma) for $1 \mathrm{~h}$, and three times in TTBS. Bands were visualized by a 3,3'-diaminobenzidine tetrahydrochloride (Sigma)/3\% hydrogen peroxide reaction. The reaction was then quenched in $50 \mathrm{mM}$ Tris$\mathrm{HCl}(\mathrm{pH} 7 \cdot 5)$, and the membranes were air dried.

Immunoblotting af amniotic fluid revealed two bands that were immunopositive for IGFBP-2. Therefore, we performed additional experiments to determine whether a phosphorylated or glycosylated form was present. First, Western immunoblot was performed with amniotic fluid samples containing 30 or $60 \mu \mathrm{g}$ total protein. The antibody used to detect phosphorylated proteins was antiphosphoserine clone PSR-45 (mouse ascites fluid; Sigma) (1:5000). On the same blot, guinea pig IGFBP-2 was detected as before with rabbit antiserum against bovine IGFBP-2. 
Table 1 Primers used to clone partial cDNA sequences of guinea pig IGF-II, IGFBP-2, IGFBP-3, IGFBP-5 and IGFBP-6

\begin{tabular}{|c|c|c|c|c|c|}
\hline & $\begin{array}{l}\text { Expected cDNA } \\
\text { length (bases) }\end{array}$ & $\begin{array}{l}\text { Primer } \\
\text { end }\end{array}$ & $\begin{array}{l}\text { Primer length } \\
\text { (bases) }\end{array}$ & Primer sequence & $\begin{array}{l}\text { Restriction } \\
\text { enzyme }\end{array}$ \\
\hline \multicolumn{6}{|l|}{ Gene } \\
\hline \multirow[t]{2}{*}{ IGF-II } & 329 bases & $5^{\prime}$ & 21 & 5' GCCCAGGCCCCAGGAAGATAC 3' (cut in plasmid) & Nco I \\
\hline & & $3^{\prime}$ & 20 & $5^{\prime}$ CGGAAGCACGGCCAAAGACG 3' (cut in plasmid) & Pst I \\
\hline \multirow[t]{2}{*}{ IGFBP-2 } & 167 bases & $5^{\prime}$ & 30 & 5' GGAAGAATTCACTGTCACAAGCATGGCCTG 3' & Eco R I \\
\hline & & $3^{\prime}$ & 28 & 5' GGAAGGATCСТССТGСТGСТCATTGTAG 3' & BamH I \\
\hline \multirow[t]{2}{*}{ IGFBP-3 } & 209 bases & $5^{\prime}$ & 29 & 5' GGAAGAATTCCAGAACTTCTCCTCCGAGTC 3' & EcoR I \\
\hline & & $3^{\prime}$ & 31 & 5' GGAAGGATCCTATCCACACACCAGCAGAAGC 3' & BamH I \\
\hline \multirow[t]{2}{*}{ IGFBP-5 } & 195 bases & $5^{\prime}$ & 30 & 5' GGAAGAATTCGCTCAAGCCAGCCCACGCAT 3' & EcoR I \\
\hline & & $3^{\prime}$ & 30 & 5' GGAAGGATCCGTCGAAGCCGTGGCACTGAA 3' & BamH I \\
\hline \multirow[t]{2}{*}{ IGFBP-6 } & 344 bases & $5^{\prime}$ & 31 & 5' GGAAGAATTCGACGAGGCGCCTTTGCGGGC 3' & EcoR I \\
\hline & & $3^{\prime}$ & 31 & 5' GGAAGGATCCGGAGGAGCGGCACTGCCGCT 3' & BamH I \\
\hline
\end{tabular}

Secondly, amniotic fluid, containing $30 \mu \mathrm{g}$ total protein, was treated with the $\mathrm{N}$-glycosylation $\mathrm{F}$ deglycosylation kit (Roche Canada, Laval, Quebec, Canada). A further sample of the amniotic fluid was not treated with the enzyme but contained the remaining reagents of the kit. The protocol was performed according to the manufacturer's instructions. Western immunoblot was performed as before with the antibovine IGFBP-2 antibody $(1: 10000)$. To determine whether the aliquots of amniotic fluid loaded on the gels contained similar amounts of protein, duplicate determinations of total protein concentration were made by the bicinchoninic acid assay (BCA Protein Assay; Pierce, Rockford, IL, USA) according to the manufacturer's instructions.

\section{RNA extraction}

Total RNA was extracted from the tissues of control and IUGR fetal guinea pigs with a guanidinium thiocyanatephenol-chloroform extraction protocol (Chomczynski \& Sacchi 1987). Final RNA pellets were dissolved in diethylpyrocarbonate-treated water, and the yield of RNA was quantified by measuring optical density at $260 \mathrm{~nm}$.

\section{Reverse transcription (RT)}

RNA was reverse transcribed by oligo(dT) priming and reverse transcriptase. An amount of $1 \mu \mathrm{g}$ total adrenal RNA extracted from fetal tissues was incubated with $0 \cdot 5 \mu \mathrm{g}$ oligo(dT) primer (Gibco BRL, Burlington, Ontario, Canada) for $10 \mathrm{~min}$ at $70{ }^{\circ} \mathrm{C}$ in $12 \mu \mathrm{l}$. Samples were then cooled on ice, and the following components added: $1 \mu$ deoxyribonucleotides (each $10 \mathrm{mM}$ ), $4 \mu \mathrm{l}$ RTbuffer (supplied with the reverse transcriptase kit), 1.5 $\mu \mathrm{l}$ $\mathrm{MgCl}_{2}(25 \mathrm{mM}), 2 \mu \mathrm{l}$ dithiothreitol $(100 \mathrm{mM}), 0.5 \mu \mathrm{l}$ RNase inhibitor $(20 \mathrm{IU} / \mu \mathrm{l})$ and $1 \mu \mathrm{l}$ reverse transcriptase

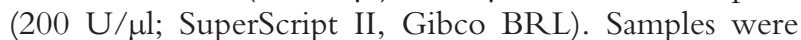
incubated for $1 \mathrm{~h}$ at $42{ }^{\circ} \mathrm{C}$ and the reaction stopped by heating to $70{ }^{\circ} \mathrm{C}$ for $15 \mathrm{~min}$. After cooling for $10 \mathrm{~min}$ at $4{ }^{\circ} \mathrm{C}, 1 \mu \mathrm{l}$ RNase $(2 \mathrm{U} / \mu \mathrm{l}$, RNase $\mathrm{H}$, Gibco BRL) was added and the solution was then heated at $37^{\circ} \mathrm{C}$ for $20 \mathrm{~min}$. The DNA was stored at $-20{ }^{\circ} \mathrm{C}$ until used.

\section{PCR}

Known cDNA sequences encoding IGF-I (Bell et al. 1990) and IGF-II (Levinovitz et al. 1992) were used to design DNA oligomers for amplification by PCR. As the guinea pig IGFBP sequences were unknown, primer pairs for IGFBP-1-6 were designed from regions of identity between the known cDNA sequences for human, rat, mouse, sheep and cattle. To facilitate cloning, the oligonucleotides were synthesized with adapters containing the restriction sites shown in Table 1. Primer pairs were synthesized at the Core Molecular Biology Facility, London Regional Cancer Centre, University of Western Ontario.

For PCR, the cDNA was supplied with $1 \mu \mathrm{l}$ of each primer $(100 \mathrm{pmol} / \mu \mathrm{l}), 1 \mu \mathrm{l}$ deoxyribonucleotides $(10 \mathrm{mM}), 5 \mu \mathrm{l} 10 \times \mathrm{PCR}$ buffer, $2.5 \mu \mathrm{MgCl}_{2}(50 \mathrm{mM})$ and water to a final volume of $50 \mu \mathrm{l}$. The tubes were incubated for $5 \mathrm{~min}$ at $94{ }^{\circ} \mathrm{C}$ to denature the template, followed by the addition of $0.5 \mu \mathrm{l}$ Taq polymerase (5 units/ $\mu \mathrm{l}$; Gibco BRL). cDNA was then amplified for 25-35 cycles in a DNA thermal cycler (Masterflex, Eppendorf Scientific Instruments, Westbury, NY, USA), with each cycle including denaturation $\left(30 \mathrm{~s}\right.$ at $\left.94^{\circ} \mathrm{C}\right)$, annealing $\left(1 \mathrm{~min}\right.$ at $\left.60-65^{\circ} \mathrm{C}\right)$ and extension $(1 \mathrm{~min}$ at $72{ }^{\circ} \mathrm{C}$ ). A final extension period of $7 \mathrm{~min}$ at $72{ }^{\circ} \mathrm{C}$ was allowed.

PCR products were mixed with $6 \times$ gel loading buffer (0.25\% bromophenol blue, $0 \cdot 25 \%$ xylene cyanol FF and $30 \%$ glycerol) and were electrophoresed with $1 \times$ Tris acetate EDTA buffer on $2 \%$ agarose gels at $100 \mathrm{~V}$ against a $1 \mathrm{~kb}$ DNA ladder (Gibco BRL). Appropriately sized bands were excised from the gel and purified with a gel extraction kit (Qiagen, Mississauga, Ontario, Canada). 


\section{Cloning of $c D N A$}

PCR products were ligated into pGEM-T vector (Promega) for heat shock uptake into competent Escherichia coli (DH5 $\alpha$, Gibco BRL) by standard methods (Maniatis et al. 1989). Insert sequences were verified by sequencing in both directions, with SP6 and T7 polymerases, at the London regional genome-sequencing core facility. The cDNAs were then isolated by restriction digestion and purified with a gel extraction kit (Qiagen).

Partial cDNA sequences of IGF-II, IGFBP-2, IGFBP-3, IGFBP-5 and IGFBP-6 were cloned successfully. The IGF-II insert was identical to the published sequence, and the IGFBP probes showed 89-96\% nucleotide sequence identity with the known cDNAs of mouse and human (data not shown).

\section{Preparation of $c R N A$ probes}

Probes were labeled by random priming with $\left[{ }^{32} \mathrm{P}\right]$ deoxyCTP, using an oligolabeling kit (Pharmacia, Baie d'Urfe, Quebec, Canada). Human probes were used for IGF-I, IGFBP-1 and IGFBP-4; we have previously demonstrated their utility in in situ hybridization experiments on guinea pig tissues (Han et al. 1999).

\section{Northern blot hybridization}

RNA samples $(20 \mu \mathrm{g})$ and a $0 \cdot 24-9 \cdot 5 \mathrm{~kb}$ RNA ladder (Gibco BRL) were electrophoresed on a 1\% denaturing agarose gel in $1 \times$ Northern buffer $(0.2 \mathrm{M} \quad 3-(N-$ morpholino)propane sulfonic acid, $5 \mathrm{mM} \mathrm{Na}_{2} \mathrm{HPO}_{4}$ and 0.5 mM EDTA, pH 7.0). The RNAs were blotted by capillary transfer onto a Zetaprobe membrane (Bio-Rad Laboratories, Richmond, CA, USA), cross-linked to the membrane and then baked at $80{ }^{\circ} \mathrm{C}$ for $1 \mathrm{~h}$.

The blots were prehybridized in Zetaprobe hybridization buffer (containing 7\% SDS, 50\% formamide, $0.1 \mathrm{mg} / \mathrm{ml}$ denatured salmon sperm DNA and $5 \times$ SSPE $\left(0.75 \mathrm{M} \mathrm{NaCl}, 44 \mathrm{mM} \mathrm{Na} \mathrm{HPO}_{4} \cdot 2 \mathrm{H}_{2} \mathrm{O}\right.$ and $5 \mathrm{mM}$ EDTA)) at $42{ }^{\circ} \mathrm{C}$. After prehybridization, the buffer was replaced with a new Zetaprobe buffer containing the ${ }^{32}$ P-labeled probe $\left(10^{6}\right.$ c.p.m.). After hybridization overnight at $42{ }^{\circ} \mathrm{C}$, the blots were washed twice for $15 \mathrm{~min}$ each in $1 \times$ SSC and $0 \cdot 1 \%$ SDS at $42{ }^{\circ} \mathrm{C}$, once for $30 \mathrm{~min}$ with $0 \cdot 1 \times$ SSC and $0 \cdot 1 \%$ SDS solution at $42{ }^{\circ} \mathrm{C}$ and twice for $30 \mathrm{~min}$ each with $0 \cdot 1 \times \mathrm{SSC}$ and $0 \cdot 1 \% \mathrm{SDS}$ at $60{ }^{\circ} \mathrm{C}$. The blots were air dried and exposed to radiographic film (BMR or XAR, Eastman Kodak) for 90 min to 10 days at $-70{ }^{\circ} \mathrm{C}$ with intensifying screens.

Before hybridizing with a new probe, the blot was stripped by washing twice for $30 \mathrm{~min}$ with $0 \cdot 01 \times$ SSC and $0.5 \%$ SDS at $80-100{ }^{\circ} \mathrm{C}$. The blots were hybridized finally with a ${ }^{32} \mathrm{P}-$ labeled $18 \mathrm{~S}$ rRNA cDNA probe to check for uniformity of RNA loading among lanes.
In situ hybridization

In situ hybridization was performed on fetal liver and placenta as described previously (Han et al. 1999). Briefly, $5 \mu \mathrm{m}$ thick sections were deparaffinized and rehydrated. After prehybridization with hybridization buffer, they were hybridized with ${ }^{35}$ S-labeled complementary RNA (cRNA) probes overnight at $55^{\circ} \mathrm{C}$ and washed at the maximum stringency of $0 \cdot 1 \times$ SSC (standard saline citrate) at $55-65{ }^{\circ} \mathrm{C}$ for $30 \mathrm{~min}$. The ${ }^{35} \mathrm{~S}$-labeled antisense and sense cRNA probes were generated from the partial cDNA sequences of guinea pig IGFBP-2 and IGFBP-3 (this paper).

After hybridization, sections were dehydrated, coated with photoemulsion (NTB-3 nuclear track emulsion (Eastman Kodak)) and exposed at $4{ }^{\circ} \mathrm{C}$ for $4-16$ weeks, depending on the strength of the autoradiographic signal on exposure to radiographic film (Biomax MR; Eastman Kodak). The photoemulsion was developed with a D-19 developer (Eastman Kodak), fixed, stained with Mayer's hematoxylin and eosin, and mounted with Permount (Fisher Scientific, Nepean, Ontario, Canada). The specificity of in situ hybridization was demonstrated by the absence of specific hybridization signal when adjacent tissue sections were subjected to an identical in situ hybridization procedure with radiolabeled sense cRNA probes.

\section{Data analysis}

Relative levels of IGF and IGFBP mRNAs on autoradiograms of Northern blots and levels of IGFBPs in plasma and amniotic fluid, as analyzed by Western ligand blotting, were quantified by laser densitometry. To correct for minor differences in loading of total RNA on Northern blots, a ratio of the relative density of each specific band to the relative density of the 18S rRNA band was calculated. Comparisons between fetuses from uterine horns with uterine artery ligation and control fetuses from the contralateral horns were made by Student's $t$-test for paired samples. Results were considered significant at $P<0 \cdot 05$.

\section{Results}

\section{Fetal morphometry}

Unilateral uterine artery ligation resulted in a smaller fetus with a smaller placenta (Table 2). Although all organs weighed less than in the control fetuses, liver weight was reduced more than body weight, while brain and adrenal glands were reduced proportionately less than body weight (Table 3).

\section{IGFBP proteins in plasma and amniotic fluid}

The principal IGFBPs in fetal guinea pig plasma migrated at $40-35,30$ and $25 \mathrm{kDa}$, corresponding to IGFBP-3, -2 
Table 2 Weights of fetus, placenta and fetal organs after unilateral uterine artery ligation in the guinea pig

\begin{tabular}{|c|c|c|c|}
\hline & Non ligated horn & Ligated horn & $\begin{array}{l}\text { Change from } \\
\text { non ligated (\%) }\end{array}$ \\
\hline Fetal weight (g) & $54 \cdot 2 \pm 6 \cdot 3$ & $34 \cdot 5 \pm 5 \cdot 8^{* \star \star}$ & $-36 \cdot 5 \pm 7 \cdot 3$ \\
\hline Placental weight (g) & $3 \cdot 82 \pm 0.65$ & $2 \cdot 45 \pm 0 \cdot 29 * *$ & $-34 \cdot 4 \pm 13 \cdot 6$ \\
\hline Liver weight $(\mathrm{g})$ & $2 \cdot 85 \pm 0 \cdot 39$ & $1 \cdot 58 \pm 0 \cdot 29^{* * *}$ & $-44 \cdot 6 \pm 8 \cdot 5$ \\
\hline Kidney weight (g) & $0 \cdot 49 \pm 0 \cdot 14$ & $0 \cdot 30 \pm 0 \cdot 09^{* \star *}$ & $-38 \cdot 6 \pm 6 \cdot 8$ \\
\hline Adrenal weight (g) & $0 \cdot 022 \pm 0.005$ & $0 \cdot 016 \pm 0.004^{* *}$ & $-25 \cdot 7 \pm 12 \cdot 3$ \\
\hline Heart weight (g) & $0 \cdot 30 \pm 0 \cdot 04$ & $0 \cdot 21 \pm 0 \cdot 04^{* *}$ & $-30 \cdot 7 \pm 14 \cdot 7$ \\
\hline Lung weight (g) & $1 \cdot 12 \pm 0 \cdot 13$ & $0 \cdot 70 \pm 0 \cdot 14^{\star \star *}$ & $-37 \cdot 4 \pm 8 \cdot 5$ \\
\hline Brain weight & $2 \cdot 13 \pm 0 \cdot 19$ & $1 \cdot 95 \pm 0 \cdot 14^{* *}$ & $-8 \cdot 5 \pm 3 \cdot 6$ \\
\hline Brain:liver weight ratio & $0 \cdot 75 \pm 0.07$ & $1 \cdot 26 \pm 0 \cdot 20^{* * *}$ & $+67 \cdot 3 \pm 20 \cdot 7$ \\
\hline
\end{tabular}

and -4 respectively. IGFBP-2 was identified by immunoblotting with antiserum against bovine IGFBP-2 (Fig. 1B). By molecular size, the 40-35 kDa doublet was identified as the glycosylated and nonglycosylated forms of IGFBP-3,

Table 3 Ratio of fetal organ weights to body weight (\%) after unilateral uterine artery ligation in the guinea pig

\begin{tabular}{lccc} 
& \multicolumn{1}{c}{ Non ligated horn } & & Ligated horn \\
\cline { 2 - 2 } Liver & $5 \cdot 27 \pm 0 \cdot 42$ & & $4 \cdot 59 \pm 0 \cdot 42^{*}$ \\
Kidneys & $0 \cdot 90 \pm 0 \cdot 22$ & & $0 \cdot 87 \pm 0 \cdot 21$ \\
Adrenals & $0 \cdot 040 \pm 0 \cdot 009$ & & $0 \cdot 047 \pm 0 \cdot 008^{*}$ \\
Heart & $0 \cdot 56 \pm 0 \cdot 02$ & & $0 \cdot 60 \pm 0 \cdot 08$ \\
Lungs & $2 \cdot 07 \pm 0 \cdot 13$ & $2 \cdot 03 \pm 0 \cdot 12$ \\
Brain & $3 \cdot 94 \pm 0 \cdot 31$ & $5 \cdot 77 \pm 1 \cdot 01^{* *}$ \\
\hline
\end{tabular}

Means \pm S.D. for paired data $(n=6)$.

${ }^{*} P<0 \cdot 05,{ }^{* *} P<0 \cdot 001$ for differences between means of paired values.

A

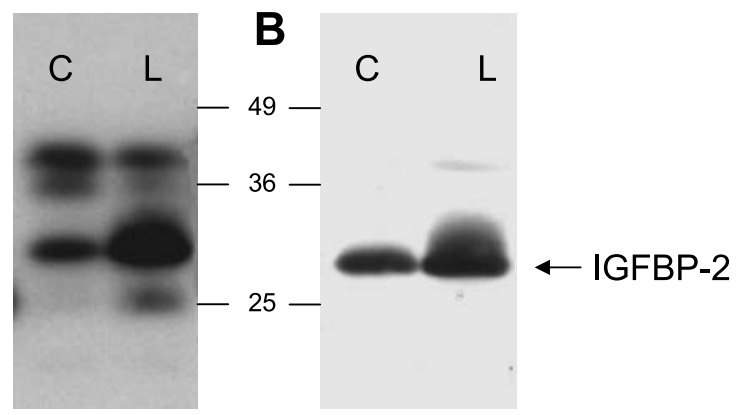

Figure 1 Parallel ligand and immunoblots of plasma from a control fetus (lane $\mathrm{C}$ ) and a fetus affected by uterine artery ligation (lane L). (A) Ligand blot probed with ${ }^{125}$ I-labeled IGF-II. (B) Immunoblot with antiserum against bovine IGFBP-2. Numbers show molecular size markers. The principal binding proteins migrated at 40-35, 30 and $25 \mathrm{kDa}$. The major $30 \mathrm{kDa}$ band is shown by immunoblotting to be IGFBP-2. By molecular size, the 40-35 kDa bands were identified as the IGFBP-3 doublet and the $25 \mathrm{kDa}$ band as IGFBP-4. and the $25 \mathrm{kDa}$ band as IGFBP-4. Antisera against human or rodent IGFBP-3 and -4 did not specifically identify these binding proteins due to lack of cross-reactivity. After uterine artery ligation, IGFBP-2 and IGFBP-4 were elevated $(P<0 \cdot 05)$ and IGFBP-3 was depressed $(P<0 \cdot 05$; Fig. 2A and C).

IGFBPs were found only at low levels in amniotic fluid of control fetuses, but amniotic fluid contained a higher molecular mass protein species not seen in plasma that was immunoreactive to IGFBP-2 (denoted IGFBP-2 L). In additional immunoblots of amniotic fluid, a phosphoserine antibody showed no band the size of IGFBP-2. The IGFBP-2 antibody detected two bands as before. There was no difference between amniotic fluid treated with glycosidase $\mathrm{F}$ enzyme and samples not treated with the enzyme. Thus, IGFBP-2 L appears not to contain phosphorylated serine residues, nor is it glycosylated by N-linkage. IGFBP-2 L and -3 were present at higher concentrations in amniotic fluid of fetuses from the horn with uterine artery ligation $(P<0 \cdot 05)$, with a similar trend for IGFBP-2 (Fig. 2B and $\mathrm{D})$. The total protein concentrations were similar in amniotic fluid from control fetuses and those from the horn with uterine artery ligation $(2 \cdot 15 \pm 0 \cdot 36$ vs $2 \cdot 11 \pm 0 \cdot 50 \mathrm{~g} / 1$ (mean \pm S.D. $)$ ), indicating that the increase in IGFBP levels in the amniotic fluid of uterine artery ligated animals was not due to oligohydramnios.

\section{IGF and IGFBP $m$ RNA expression in normal fetal tissues and placenta}

The relative expression of IGF and IGFBP mRNAs is shown in Fig. 3. IGF-I and -II mRNA was identified by Northern blot in all tissues examined. There were three IGF-I transcripts (about $4 \cdot 1,2 \cdot 7$ and $2 \cdot 3 \mathrm{~kb}$ ). IGF-II was present as two major (about 5.5 and $3 \cdot 1 \mathrm{~kb}$ ) and six minor transcripts (not shown) with relatively greater expression in liver than in placenta or muscle. IGFBP-1 mRNA (about $2.6 \mathrm{~kb}$ ) was expressed at very low levels in fetal 



D $\%$ of C

Figure 2 ( $A$ and $B$ ) Ligand blots of guinea pig fetal plasma $(A)$ and amniotic fluid $(B)$ at 55-57 days of gestation probed with ${ }^{125}$ I-labeled IGF-II. The first six lanes in each blot are from control fetuses and the second six lanes from fetuses affected by uterine artery ligation. Numbers show molecular size markers. Amniotic fluid contained a protein not seen in plasma that was immunoreactive to IGFBP-2 (denoted IGFBP-2 L). (C)

Densitometric analysis for fetal plasma expressed as percentage change relative to control plasma. Levels of IGFBP-2 and -4 increased after uterine artery ligation, whereas IGFBP-3 decreased. (D) Densitometric analysis of amniotic fluid expressed as percentage change relative to control amniotic fluid. IGFBPs were present at low concentration in control conditions, but IGFBP- $2 \mathrm{~L}$ and -3 rose after uterine artery ligation, with a similar trend for IGFBP-2. ${ }^{*} P<0 \cdot 05$ for difference between means of paired values.

liver (not shown) and could not be detected in placenta or muscle. IGFBP-2 mRNA was present as one major transcript (about $3.3 \mathrm{~kb}$ ), the relative level of expression being liver $>$ placenta $>$ muscle. The major IGFBP-3 mRNA transcript (about $3.7 \mathrm{~kb}$ ) had a similar pattern of relative expression. Expression of the major IGFBP-4 mRNA transcript (about $4 \cdot 1 \mathrm{~kb}$ ) was similar in the three tissues. IGFBP-5 mRNA was found in placenta and muscle as three transcripts (about $7 \cdot 0,3.2$ and $2 \cdot 1 \mathrm{~kb}$ ), with the $7 \cdot 0 \mathrm{~kb}$ transcript being most prominent. In liver, the most prominent transcript was $2 \cdot 1 \mathrm{~kb}$; the $7 \cdot 0 \mathrm{~kb}$ transcript could not be detected. Two transcripts of
IGFBP-6 mRNA were identified (about 3.4 and $2.9 \mathrm{~kb}$ ), the relative level of expression of the smaller transcript being muscle>placenta>liver. The larger transcript was seen mainly in liver.

In sections of fetal liver, expression of IGFBP-2 mRNA was limited to the hepatocytes (Fig. 4); mRNA was not expressed in hematopoietic tissues. The signal for IGFBP-3 mRNA was restricted to a subset of cells, probably Kupffer cells (data not shown), as described previously in rodents (Zimmermann et al. 2000). Expression of IGFBP-2 and -3 mRNA in placenta was as previously described (Han et al. 1999). 


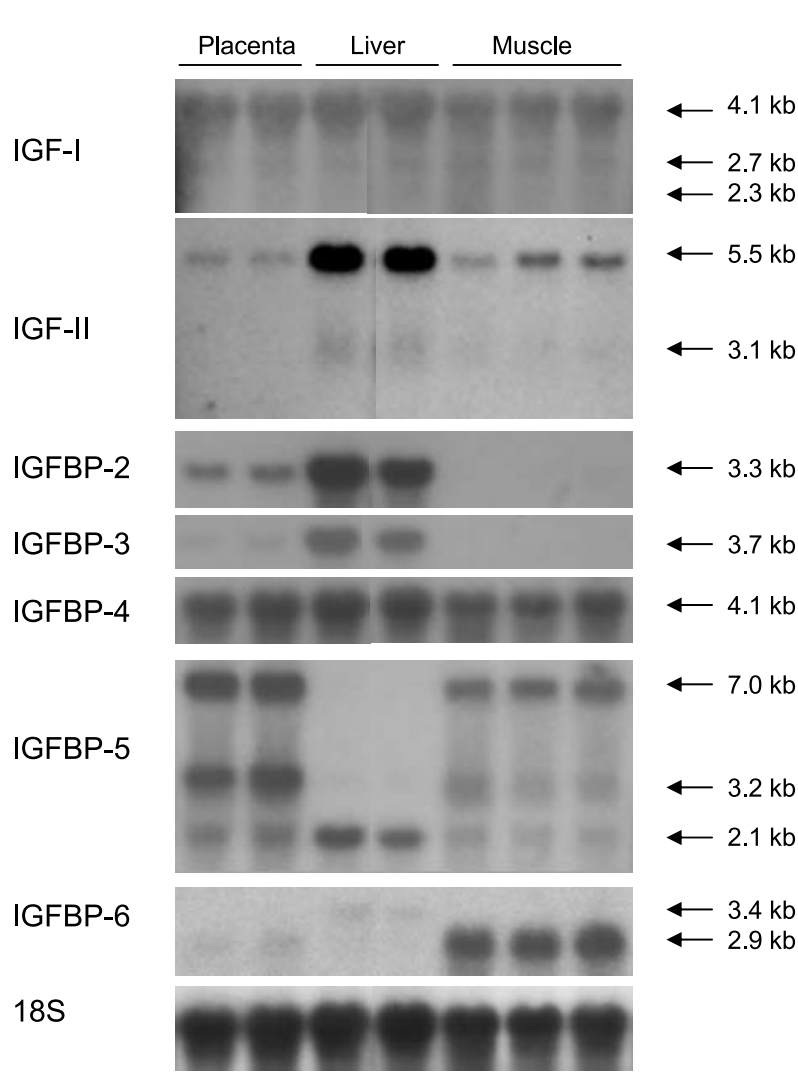

Figure 3 Northern blot analysis of total RNA from guinea pig placenta, fetal liver and fetal muscle at 55-57 days of gestation. Similar amounts of total RNA $(20 \mu \mathrm{g})$ were loaded in each lane, as confirmed by the signal for $18 \mathrm{~S}$ rRNA. Relatively higher levels of IGF-II, IGFBP-2 and IGFBP-3 were seen in fetal liver. The principal IGFBP-5 transcript in fetal liver differed from that in placenta and fetal muscle, with the $7.0 \mathrm{~kb}$ transcript being predominant in placenta and muscle while the $2 \cdot 1 \mathrm{~kb}$ transcript was predominant in fetal liver. IGFBP-6 was more strongly expressed in fetal muscle than in either placenta or fetal liver.

IGF and IGFBP $m R N A$ expression in fetal tissues and placenta from the ligated horn

In fetal liver, expression of IGFBP-2 mRNA increased $1 \cdot 7$-fold after uterine artery ligation $(P<0 \cdot 01$; Fig. $5 \mathrm{~A}$ and $B)$. No significant change occurred in hepatic expression of IGF-I and -II mRNA or IGFBP-3 and -5 mRNA. There was no significant change in IGF or IGFBP mRNA expression in fetal skeletal muscle.

In placenta, a small increase in expression of IGFBP-4 mRNA (14\%; $P<0 \cdot 01)$ was observed after uterine artery ligation (Fig. $5 \mathrm{C}$ and $\mathrm{D}$ ). There was a trend toward a $62 \%$ decrease in IGFBP-5 mRNA expression that reached borderline significance $(P=0 \cdot 06$; Fig. 5C and E). No change occurred in placental expression of IGF-I and II mRNA or IGFBP-1, -2 or -5 mRNA.
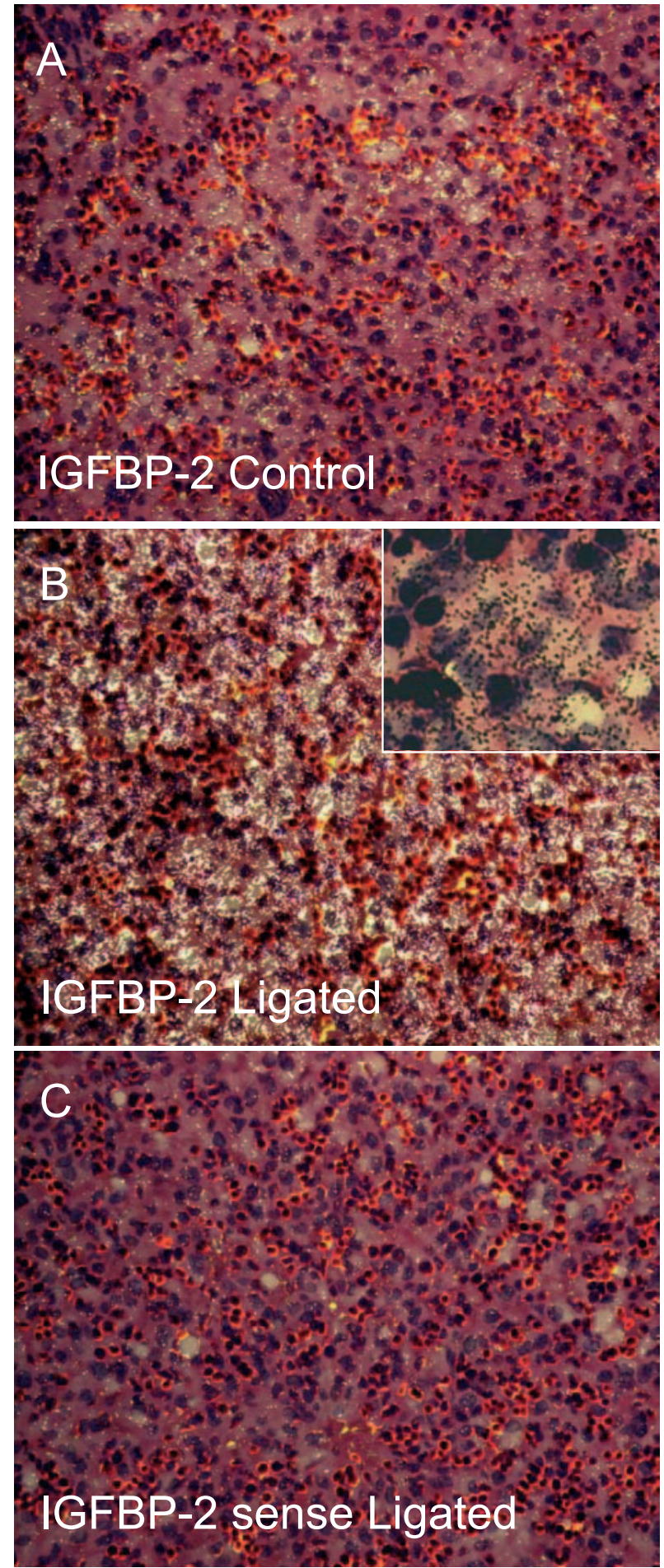

Figure 4 Localization of IGFBP-2 mRNA in fetal liver by in situ hybridization. (A and $\mathrm{B}$ ) In both control fetuses and fetuses affected by uterine artery ligation, the IGFBP- 2 mRNA is restricted to the hepatocytes (inset); message is not expressed by hematopoietic tissue. (C) No specific signal was seen when liver sections were incubated with a sense IGFBP-2 cRNA probe. Magnification $\times 20$. Inset in $(B)$ is magnified $\times 40$. 
A

IGFBP-2

$18 \mathrm{~S}$

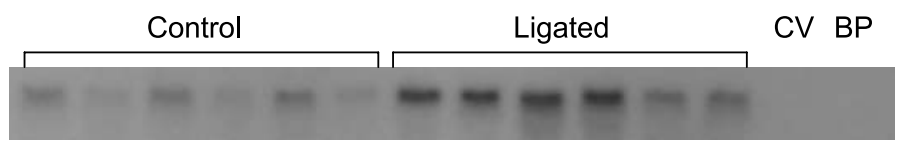

B

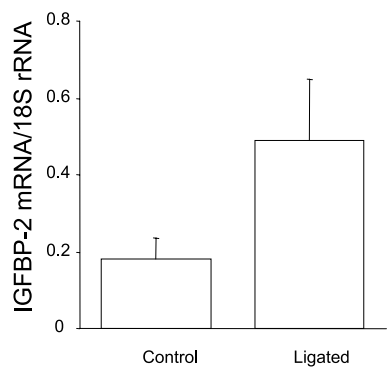

C

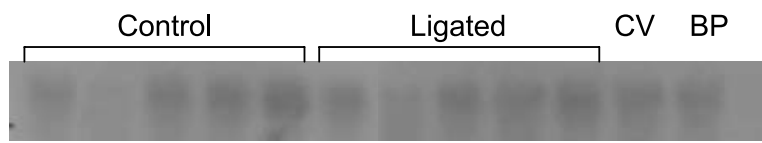

IGFBP-5

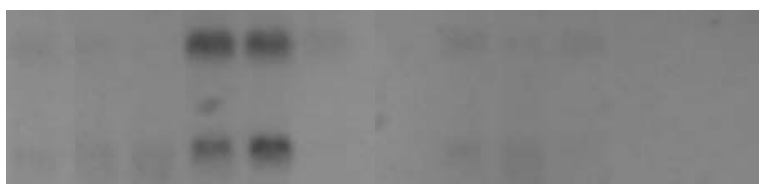

$18 S$



D
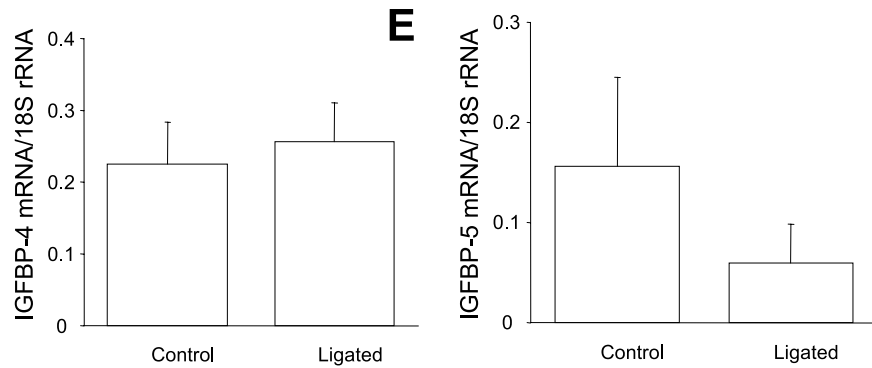

Figure 5 Northern blot analysis of total RNA from guinea pig fetal liver (A) and placenta (C) at 55-57 days of gestation. The first six lanes in each blot are from control fetuses and the second six lanes from fetuses affected by uterine artery ligation. In addition, RNA from chorionic villi $(\mathrm{CV})$ and basal plate decidua (BP) of human placenta were run as routine controls. Histograms show the ratio of the specific mRNA to $18 \mathrm{~S}$ rRNA (mean \pm S.D.) for the two groups of fetuses. In fetal liver (B), there was a significant increase in IGFBP-2 mRNA $(P<0 \cdot 01)$. In placenta $(D)$, there was a small but significant increase in IGFBP-4 mRNA after uterine artery ligation $(P<0 \cdot 01)$, and a trend toward decreased IGFBP-5 expression $(P=0 \cdot 06)$.

\section{Discussion}

As previously shown (Lafeber et al. 1984, Carter \& Detmer 1990, Detmer et al. 1991), uterine artery ligation in guinea pigs led to a decrease in placental size and asymmetric restriction of fetal growth. This is a useful model to study
IUGR caused by a reduction in oxygen and substrate supply to the fetus (Carter 1993). Previous studies have demonstrated that IGF-I and -II are required to achieve normal fetal and placental growth. In mice carrying a null mutation for either Igf1 or Igf2, fetal size is reduced by $40 \%$ (DeChiara et al. 1990, Liu et al. 1993). Our results are 
consistent with a role for the IGF system in slowing fetal growth after uterine artery ligation. They suggest that tissue-specific alterations in the expression of IGFBPs may be important.

\section{Proteins in plasma and amniotic fluid}

The most abundant IGFBP in adult guinea pig plasma is IGFBP-3 (Sohlström et al. 1998b), and this was present in fetal plasma as a $40-35 \mathrm{kDa}$ doublet corresponding to the glycosylated and nonglycosylated forms. However, the principal IGFBP in fetal guinea pig plasma was identified by molecular mass and immunoblotting as IGFBP-2 (Fig. 1). IGFBP-4 was present as a $25 \mathrm{kDa}$ band. We did not detect the additional band that has been described for adult guinea pigs and is thought to include IGFBP-1 protein (Sohlström et al. 1998b).

After uterine artery ligation, we observed a strong increase in the concentration of IGFBP-2, the principal $\mathrm{BP}$ in fetal plasma. This mimics the rise in IGFBP-1 and IGFBP-2 levels seen in human IUGR (Chard 1994, Langford et al. 1994) or after mechanical restriction of uterine blood flow in sheep (McLellan et al. 1992). In the rat, uterine artery ligation is accompanied by an increase in IGFBP-1, while IGFBP-2 remains constant (Price et al. 1992a, Unterman et al. 1993). There was a decrease in the concentration of IGFBP-3 in fetal plasma after uterine artery ligation. Similarly, there is a positive correlation of birth weight and placental weight to IGFBP-3 levels in cord blood (Ong et al. 2000). It should be noted that IGFBP-3 is absent in rat plasma (Lee et al. 1999). Elevated levels of IGFBP-2 and reduced IGFBP-3 levels have also been seen in maternal blood after food restriction in guinea pigs (Sohlström et al. 1998b, Roberts et al. 2001, 2002). IGFBP-4 levels in fetal plasma were elevated after uterine artery ligation, as is the case after food restriction in adult, nonpregnant guinea pigs (Sohlström et al. 1998a).

The amniotic fluid of control fetuses contained only small amounts of IGFBPs, but higher concentrations were seen after uterine artery ligation. There is, again, a similarity to human IUGR, where elevated IGFBP-1 levels are seen in amniotic fluid (Hakala-Ala-Pietila et al. 1993). The increase in IGFBP-2 concentration was greater in amniotic fluid than plasma and included a band of larger molecular size that did not appear in plasma. Moreover, IGFBP-3 decreased in plasma but increased in amniotic fluid. Total protein concentration was similar in amniotic fluid from control fetuses and those from the horn with uterine artery ligation. Thus, we do not think the increased concentrations can be explained by similar amounts of IGFBP being distributed in a smaller volume of amniotic fluid due to oligohydramnios. It is possible that renal handling of IGFBPs is altered in growth-restricted fetuses.
IGF and IGFBP $m R N A$ expression in fetal tissues and placenta

IGF-II and IGFBP-2, -3, -5 and -6 mRNA expression in fetal tissues and placenta was examined by cDNA probes, which were generated by RT-PCR of guinea pig total RNA, using oligonucleotide primers based on the known human sequences. Human rather than rodent sequences were used because previous hybridization studies suggested that the guinea pig mRNAs may be more similar to those of humans than rodents (Han et al. 1999). There was a satisfactory degree of homology between the nucleotide sequences of the probes and published cDNAs for human as well as mouse. Human probes were used for IGF-I, IGFBP-1 and IGFBP-4; we have previously demonstrated their utility in in situ hybridization experiments on guinea pig tissues (Han et al. 1999).

Altered levels of IGFs and IGFBPs in maternal and fetal plasma are probably of limited importance for placental growth and function, which is more likely to be regulated by the IGF system through paracrine and autocrine mechanisms (Han \& Carter 2000). There was a small increase in placental IGFBP-4 mRNA expression after uterine artery ligation. In addition, we saw a strong tendency for decreased expression of IGFBP-5 mRNA (Fig. 5C and D). We have shown by in situ hybridization that IGFBP-5 mRNA is expressed in the nonvascularized (marginal and interlobular) syncytium of the placenta and IGF-II mRNA in the labyrinth (Han et al. 1999). Earlier, we suggested that interaction between IGF-II and IGFBP-5 mRNA is involved in the vascularization of the placenta by fetal vessels (Han et al. 1999). Thus, the decreased expression of IGFBP-5 mRNA indicated by the present study, probably in the marginal and interlobular syncytium, could contribute to the restriction of placental growth.

Growth restriction in the fetus was asymmetric, with a proportionately greater reduction in liver weight and sparing of the brain (Table 3). We observed a strong increase in IGFBP-2 mRNA in fetal liver. This observation is consistent with a role for IGFBP-2 in regulating fetal growth after uterine artery ligation in guinea pigs. Muscle mass also is disproportionately reduced after uterine artery ligation. IGFBP-6 was highly expressed in fetal muscle and has the potential to affect muscle growth by inhibiting proliferation and differentiation (Bach et al. 1994, Ewton \& Florini 1995). However, we saw no change in IGF or IGFBP mRNA expression in skeletal muscle.

\section{Origin of circulating IGFBPs}

A consistent finding in human fetal growth restriction is a rise in the IGFBP-1 levels of fetal blood (Chard 1994). Later it was shown that the increase in IGFBP-1 is restricted to the phosphorylated isoform, which strongly inhibits IGF action, whereas levels of the nonphosphorylated isoform of IGFBP-1 are similar in small and average 
for gestational age infants (Iwashita et al. 1998). Circulating IGFBP-1 levels also rise in response to fetal hypoxia, and the Igfbp-1 gene has a consensus sequence for the hypoxiaresponse element that binds hypoxia-inducible factor (Tazuke et al. 1998). The question arises of whether the IGFBP in fetal blood is placental or fetal in origin. This has not been resolved by experiments with overexpression of hIGFBP-1 in transgenic mice. In one hIGFBP-1 transgenic line, expression of the transgene in the mother led to growth restriction that was independent of the fetal genotype, suggesting it was due to placental insufficiency (Crossey et al. 2002). On the other hand, when the hIGFBP-1 transgene was controlled by the $\alpha$-fetoprotein promoter, restricting expression to fetal liver, gut and brain, fetal weight was reduced by $20 \%$ from E14.5 (Watson et al. 2002, Carter et al. 2004).

In the guinea pig fetus, IGFBP-1 mRNA was expressed at very low levels in fetal liver and did not change after uterine artery ligation. IGFBP-1 protein could not be detected in fetal plasma or amniotic fluid by ligand blot. Some anomalies in the endocrine system of guinea pigs are attributed to divergences in the amino-acid sequences of regulatory hormones, including pancreatic insulin (Keightley \& Fuller 1996). A reduced role for IGFBP-1 in guinea pigs would fit this pattern, since IGFBP-1 normally is regulated by insulin (O'Brien et al. 2001). In guinea pigs, IGFBP-2 seems to play a more prominent role than IGFBP-1, and this BP was elevated in fetal plasma after uterine artery ligation. Increased plasma levels of IGFBP2 have been reported in growth-restricted human fetuses (Langford et al. 1994). In growth-restricted rat fetuses, there is increased abundance of both IGFBP-1 and IGFBP-2 mRNA in liver, but only IGFBP-1 rises in fetal plasma (Price et al. 1992a,b). The reason for the increased prominence of IGFBP-2 in guinea pig fetuses subjected to stress such as hypoxia and undernutrition is unknown, but may be due to differences in the regulatory regions of the IGFBP-1 and IGFBP-2 genes. Thus, further elucidation of the guinea pig genes for IGFBP-1 and IGFBP-2 is needed to explain the phylogenetic differences among species. IGFBP-2 in guinea pig fetal plasma is probably of hepatic origin, since the relative level of expression of IGFBP-2 mRNA is greater in liver than in other tissues examined (Fig. 3) and increases further after uterine artery ligation (Fig. 5A and B).

The evidence from our studies suggests that the increase in circulating IGFBPs in growth-restricted fetuses is hepatic, and not placental, in origin (Han \& Carter 2000). For example, the plasma level of IGFBP-1 rises and hepatic IGFBP-1 mRNA expression increases in the sheep fetus after maternal fasting (Osborn et al. 1992) or mechanical restriction of uterine blood flow (McLellan et al. 1992), yet the sheep has a nondeciduate placenta. Elevated IGFBP-1 in maternal blood is more likely to be of decidual origin (Martina et al. 1997). In addition, the proportional increase in IGFBP-2 in the circulation of growth-restricted fetuses without changes in IGFs indicates that there is a causal relationship between the increase in IGFBP-2 and fetal growth. That IGFBP-2 is a predominant IGFBP, in contrast to IGFBP-1 in other species, may be of phylogenetic significance.

\section{Acknowledgements}

This study was supported by the Danish Medical Research Council (A M C) and by the Medical Research Council of Canada (V K M H). We gratefully acknowledge the skilled technical assistance of Lis Teusch and Sam Katsios. The authors declare that there is no conflict of interest that would prejudice the impartiality of this scientific work.

\section{References}

Bach LA, Hsieh S, Brown AL \& Rechler MM 1994 Recombinant human insulin-like growth factor (IGF)-binding protein-6 inhibits IGF-II-induced differentiation of L6A1 myoblasts. Endocrinology 135 2168-2176.

Bell GI, Stempien MM, Fong NM \& Seino S 1990 Sequence of a cDNA encoding guinea pig IGF-I. Nucleic Acids Research 184275

Carter AM 1993 Current topic: restriction of placental and fetal growth in the guinea-pig. Placenta 14 125-135.

Carter AM \& Detmer A 1990 Blood flow to the placenta and lower body in the growth-retarded guinea pig fetus. Journal of Developmental Physiology 13 261-269.

Carter AM, Hills F, O'Gorman DB, Roberts CT, Sooranna SR, Watson CS \& Westwood M 2004 The insulin-like growth factor system in mammalian pregnancy. Placenta 25 (Suppl 1) S53-S56.

Chard T 1994 Insulin-like growth factors and their binding proteins in normal and abnormal human fetal growth. Growth Regulation 4 91-100.

Chomczynski P \& Sacchi N 1987 Single-step method of RNA isolation by acid guanidinium thiocyanate-phenol-chloroform extraction. Analytical Biochemistry 162 156-159.

Clemmons DR 1997 Insulin-like growth factor binding proteins and their role in controlling IGF actions. Cytokine and Growth Factor Reviews 8 45-62.

Crossey PA, Pillai CC \& Miell JP 2002 Altered placental development and intrauterine growth restriction in IGF binding protein-1 transgenic mice. Journal of Clinical Investigation 110 411-418.

Daughaday WH \& Rotwein P 1989 Insulin-like growth factors I and II. Peptide, messenger ribonucleic acid and gene structures, serum, and tissue concentrations. Endocrine Reviews 10 68-91.

DeChiara TM, Efstratiadis A \& Robertson EJ 1990 A growth-deficiency phenotype in heterozygous mice carrying an insulin-like growth factor II gene disrupted by targeting. Nature 345 $78-80$.

Delhanty PJ \& Han VK 1993 The expression of insulin-like growth factor (IGF)-binding protein-2 and IGF-II genes in the tissues of the developing ovine fetus. Endocrinology 132 41-52.

Detmer A \& Carter AM 1992 Factors influencing the outcome of ligating the uterine artery and vein in a guinea pig model of intrauterine growth retardation. Scandinavian Journal of Laboratory Animal Science 19 9-16.

Detmer A, Gu W \& Carter AM 1991 The blood supply to the heart and brain in the growth retarded guinea pig fetus. Journal of Developmental Physiology 15 153-160.

D’Ercole AJ \& Underwood LE 1980 Ontogeny of somatomedin during development in the mouse. Serum concentrations, molecular forms, binding proteins, and tissue receptors. Developmental Biology $7933-45$. 
Ewton DZ \& Florini JR 1995 IGF binding proteins-4, -5 and -6 may play specialized roles during L6 myoblast proliferation and differentiation. Journal of Endocrinology 144 539-553.

Hakala-Ala-Pietila TH, Koistinen RA, Salonen RK \& Seppala MT 1993 Elevated second-trimester amniotic fluid concentration of insulin-like growth factor binding protein-1 in fetal growth retardation. American Journal of Obstetrics and Gynecology 169 35-39.

Han VKM \& Carter AM 2000 Insulin-like growth factors and their binding proteins in the placenta of man and laboratory animals. Placenta 21 289-305.

Han VKM, Carter AM, Chandarana S, Tanswell B \& Thompson K 1999 Ontogeny of expression of insulin-like growth factor (IGF) and IGF binding protein mRNAs in the guinea-pig placenta and uterus. Placenta 20 361-377.

Iwashita M, Sakai K, Kudo Y \& Takeda Y 1998 Phosphoisoforms of insulin-like growth factor binding protein-1 in appropriate-forgestational-age and small-for-gestational-age fetuses. Growth Hormone and IGF Research 8 487-493.

Jones CT, Lafeber HN, Price DA \& Parer JT 1987 Studies on the growth of the fetal guinea pig. Effects of reduction in uterine blood flow on the plasma sulphation-promoting activity and on the concentration of insulin-like growth factors-I and -II. Journal of Developmental Physiology 9 181-201.

Keightley MC \& Fuller PJ 1996 Anomalies in the endocrine axes of the guinea pig: relevance to human physiology and disease. Endocrine Reviews 17 30-44.

Lafeber HN, Rolph TP \& Jones CT 1984 Studies on the growth of the fetal guinea pig. The effects of ligation of the uterine artery on organ growth and development. Journal of Developmental Physiology 6 $441-459$.

Langford K, Blum W, Nicolaides K, Jones J, McGregor A \& Miell J 1994 The pathophysiology of the insulin-like growth factor axis in fetal growth failure: a basis for programming by undernutrition? European Journal of Clinical Investigation 24 851-856.

Lee CY, Cohen FJ, Wu HB, Ooi GT \& Rechler MM 1999 The absence of $150-\mathrm{kDa}$ insulin-like growth factor complexes in fetal rat serum is not due to a lack of functional acid-labile subunit. Hormone and Metabolic Research 31 182-185.

Levinovitz A, Norstedt G, van den Berg S, Robinson IC \& Ekström TJ 1992 Isolation of an insulin-like growth factor II cDNA from guinea pig liver: expression and developmental regulation. Molecular and Cellular Endocrinology 89 105-110.

Liu JP, Baker J, Perkins AS, Robertson EJ \& Efstratiadis A 1993 Mice carrying null mutations of the genes encoding insulin-like growth factor I (Igf-1) and type 1 IGF receptor (IGF1r). Cell 75 59-72.

McLellan KC, Hooper SB, Bocking AD, Delhanty PJ, Phillips ID, Hill DJ \& Han VK 1992 Prolonged hypoxia induced by the reduction of maternal uterine blood flow alters insulin-like growth factor-binding protein-1 (IGFBP-1) and IGFBP-2 gene expression in the ovine fetus. Endocrinology 131 1619-1628.

Maniatis T, Sambrook J \& Fritsch EF 1989 Molecular Cloning: A Laboratory Manual. Cold Spring Harbor, NY: Cold Spring Harbor Laboratory.

Martina NA, Kim E, Chitkara U, Wathen NC, Chard T \& Giudice LC 1997 Gestational age-dependent expression of insulin-like growth factor-binding protein-1 (IGFBP-1) phosphoisoforms in human extraembryonic cavities, maternal serum, and decidua suggests decidua as the primary source of IGFBP-1 in these fluids during early pregnancy. Journal of Clinical Endocrinology and Metabolism 82 1894-1898.

O’Brien RM, Streeper RS, Ayala JE, Stadelmaier BT \& Hornbuckle LA 2001 Insulin-regulated gene expression. Biochemical Society Transactions $29552-558$.

Ong K, Kratzsch J, Kiess W, Costello M, Scott C \& Dunger D 2000 Size at birth and cord blood levels of insulin, insulin-like growth factor I (IGF-I), IGF-II, IGF-binding protein-1 (IGFBP-1), IGFBP-3, and the soluble IGF-II/mannose-6-phosphate receptor in term human infants. The ALSPAC Study Team. Avon Longitudinal Study of Pregnancy and Childhood. Journal of Clinical Endocrinology and Metabolism 85 4266-4269.

Osborn BH, Fowlkes J, Han VKM \& Freemark M 1992 Nutritional regulation of insulin-like growth factor-binding protein gene expression in the ovine fetus and pregnant ewe. Endocrinology 131 1743-1750.

Price WA, Rong L, Stiles AD \& d'Ercole AJ 1992a Changes in IGF-I and -II, IGF binding protein, and IGF receptor transcript abundance after uterine artery ligation. Pediatric Research 32 291-295.

Price WA, Stiles AD, Moats-Staats BM \& D'Ercole AJ $1992 b$ Gene expression of insulin-like growth factors (IGFs), the type 1 IGF receptor, and IGF-binding proteins in dexamethasone-induced fetal growth retardation. Endocrinology 130 1424-1432.

Roberts CT, Sohlstrom A, Kind KL, Grant PA, Earl RA, Robinson JS, Khong TY, Owens PC \& Owens JA 2001 Altered placental structure induced by maternal food restriction in guinea pigs: a role for circulating IGF-II and IGFBP-2 in the mother? Placenta 22 (Suppl A) S77-S82.

Roberts CT, Kind KL, Earl RA, Grant PA, Robinson JS, Sohlstrom A, Owens PC \& Owens JA 2002 Circulating insulin-like growth factor (IGF)-I and IGF binding proteins -1 and -3 and placental development in the guinea-pig. Placenta 23 763-770.

Rotwein P \& Hall LJ 1990 Evolution of insulin-like growth factor II: characterization of the mouse IGF-II gene and identification of two pseudo-exons. DNA and Cell Biology 9 725-735.

Soares MB, Turken A, Ishii D, Mills L, Episkopou V, Cotter S, Zeitlin S \& Efstratiadis A 1986 Rat insulin-like growth factor II gene. A single gene with two promoters expressing a multitranscript family. Journal of Molecular Biology 192 737-752.

Sohlström A, Katsman A, Kind KL, Grant PA, Owens PC, Robinson JS \& Owens JA 1998a Effects of acute and chronic food restriction on the insulin-like growth factor axis in the guinea pig. Journal of Endocrinology 157 107-114.

Sohlström A, Katsman A, Kind KL, Roberts CT, Owens PC, Robinson JS \& Owens JA 19986 Food restriction alters pregnancy-associated changes in IGF and IGFBP in the guinea pig. American Journal of Physiology - Endocrinology and Metabolism 274 E410-E416.

Tazuke SI, Mazure NM, Sugawara J, Carland G, Faessen GH, Suen LF, Irwin JC, Powell DR, Giaccia AJ \& Giudice LC 1998 Hypoxia stimulates insulin-like growth factor binding protein 1 (IGFBP-1) gene expression in HepG2 cells: a possible model for IGFBP-1 expression in fetal hypoxia. PNAS 95 10188-10193.

Unterman TG, Simmons RA, Glick RA \& Ogata ES 1993 Circulating levels of insulin, insulin-like growth factor-I (IGF-I), IGF-II, and IGF-binding proteins in the small for gestational age fetal rat. Endocrinology 132 327-336.

Watson CS, Peres M, Bialek P, Yee SP \& Han VKM 2002 Hepatic overexpression of insulin-like growth factor binding protein-1 in fetal mice: effects on organ growth. 84th Annual Meeting of the Endocrine Society, San Francisco, California, 2002. Abstract P2-188.

Winger QA, de los Rios P, Han VK, Armstrong DT, Hill DJ \& Watson AJ 1997 Bovine oviductal and embryonic insulin-like growth factor binding proteins: possible regulators of 'embryotrophic' insulin-like growth factor circuits. Biology of Reproduction 56 1415-1423.

Zimmermann EM, Li L, Hoyt EC, Pucilowska JB, Lichtman S \& Lund PK 2000 Cell-specific localization of insulin-like growth factor binding protein mRNAs in rat liver. American Journal of Physiology - Gastrointestinal and Liver Physiology 278 G447-G457.

Received 1 September 2004 Accepted 20 September 2004 